\title{
Analisis Pengaruh Tingkat Investasi, Pendapatan Asli Daerah dan Tenaga Kerja Terhadap PDRB Provinsi Jambi
}

\author{
Siti Marlina AZ, Siska Pebrina \\ Sekolah tinggi Ilmu Ekonomi Graha Karya Muara Bulian
}

\begin{abstract}
Economic development is the process of changing the undeveloped economic structure by means of capital investment and human investment aimed at increasing the prosperity of the population or rising income per capita. The purpose of this study was to find out about the effect of the level of investment, local revenue, labor on the GRDP of Jambi Province. In this study using qualitative and quantitative approaches. The variables used in this study are independent variables, namely the level of investment, Regional Original Income and labor. The dependent variable is Gross Domestic Regional Income. Data analysis tool used multiple regression, $T$ test, $F$ test and determination. The results of the research show that the investment level is still low due to high economic licensing. The level of investment, $P A D$ and labor has a significant influence seen from the joint test, namely the determination of 11.036. In the end, research was targeted so that the economy of Jambi province increased by facilitating all processes in licensing activities and increasing PAD
\end{abstract}

Keywords: Investment Level; Regional Original Income; Labor and Gross Regional Domestic Income.

DOI: 10.33087 /ekonomis.v3i1.54

\section{PENDAHULUAN}

Pembangunan ekonomi adalah proses merubah struktur ekonomi yang belum berkembang dengan jalan capital investment dan human investment bertujuan untuk meningkatkan kemakmuran penduduk atau income per capita naik (Hasibuan, 1987). Suparmoko (2002), pembangunan ekonomi adalah usaha-usaha untuk meningkatkan taraf hidup suatu bangsa yang seringkali diukur dengan tinggi rendahnya pendapatan riil perkapita. Jadi tujuan pembangunan ekonomi disamping untuk meningkatkan pendapatan nasional riil juga untuk meningkatkan produktivitas. Pembangunan ekonomi dapat memberikan kepada manusia kemampuan yang lebih besar untuk menguasai alam sekitarnya dan mempertinggi tingkat kebebasannya dalam mengadakan suatu tindakan tertentu. Pertumbuhan ekonomi adalah sebagian dari perkembangan kesejahteraan masyarakat yang diukur dengan besarnya pertumbuhan domestik regional bruto perkapita (PDRB perkapita) (Zaris, 1987). Tingginya tingkat pertumbuhan ekonomi yang ditunjukkan dengan tingginya nilai PDRB menunjukkan bahwa daerah tersebut mengalami kemajuan dalam perekonomian. Provinsi-Provinsi yang berada di pulau sumatera ternyata mempunyai pertumbuhan ekonomi yang tergolong rendah. Ini dikarenakan sedikitnya sumber daya alam yang dimiliki oleh Provinsi-Provinsi yang berada di pulau Sumatera. Sumber daya alam ini merupakan salah satu faktor pendorong pertumbuhan daerah, selain pola investasi dan perkembangan prasarana transportasi (Zaris, 1987). Salah satu indikator keberhasilan pelaksanaan pembangunan yang dapat dijadikan tolok ukur secara makro adalah pertumbuhan ekonomi (Adisetiawan, 2018). Akan tetapi, meskipun telah digunakan sebagai indikator pembangunan, pertumbuhan ekonomi masih bersifat umum dan belum mencerminkan kemampuan masyarakat secara individual. Pembangunan daerah diharapkan akan membawa dampak positif pula terhadap pertumbuhan ekonomi. Pertumbuhan ekonomi daerah dapat dicerminkan dari perubahan PDRB dalam suatu wilayah begitu pula di propinsi Jambi.

Penggalian pendapatan daerah, peningkatan peran serta swasta dan peningkatan partisipasi tenaga kerja lokal sebagai modal pembangunan daerah diharapkan menjadi salah satu faktor pendorong pertumbuhan daerah. Pemerintah daerah harus melaksanakan pendekatan perencanaan pembangunan daerah dari bawah ke atas (bottom up) agar pembangunan yang dilaksanakan daerah merupakan keinginan bersama dan sesuai dengan potensi yang ada agar kesinambungan pembangunan dapat tercapai (Adisetiawan, 2017). Berdasarkan uraian di atas, terlihat bahwa tingkat investasi, pendapatan asli daerah dan tenaga kerja mempunyai pengaruh terhadap pertumbuhan ekonomi di Provinsi Jambi. Apabila nilai dari masing-masing variabel meningkat maka peningkatan juga terjadi pada pertumbuhan ekonomi dalam hal ini adalah PDRB. Apabila terjadi penurunan dari variabel-variabel tersebut penurunan juga terjadi terhadap PDRB, dari fenomena tersebut di atas maka perlu adanya suatu penelitian yang diharapkan dapat memberikan rekomendasi demi kelangsungan pertumbuhan ekonomi di Provinsi Jambi. Tujuan penelitian ini adalah untuk mengetahui 
pengaruh tingkat investasi, pendapatan asli daerah, dan tenaga kerja terhadap PDRB Provinsi Jambi, dan seberapa besar pengaruh masing-masing variabel tingkat investasi, pendapatan asli daerah, dan tenaga kerja terhadap PDRB Provinsi Jambi.

\section{Tinjauan Pustaka}

\section{Pengertian pertumbuhan ekonomi dan pembangunan ekonomi}

Pertumbuhan ekonomi berarti perkembangan kegiatan dalam perekonomian yang menyebabkan barang dan jasa yang diproduksikan dalam masyarakat bertambah dan kemakmuran masyarakat meningkat (Sukirno, 1994). Pertumbuhan ekonomi diartikan sebagai kenaikan GDP (Gross Domestic Product) tanpa memandang bahwa kenaikan itu lebih besar atau lebih kecil dari pertumbuhan penduduk dan tanpa memandang apakah ada perubahan dalam struktur ekonominya. Menurut Zaris (1987) pertumbuhan ekonomi adalah sebagian dari perkembangan kesejahteraan masyarakat yang diukur dengan besarnya pertumbuhan domestik regional bruto per kapita (PDRB per kapita). Samuelson (1995) mendefinisikan bahwa pertumbuhan ekonomi menunjukkan adanya perluasan atau peningkatan dari Gross Domestic Product potensial/output dari suatu negara. Ada 4 faktor yang menyebabkan pertumbuhan ekonomi: (Adisetiawan, 2014)

1. Sumber Daya Manusia, kualitas input tenaga kerja, atau sumber daya manusia merupakan faktor terpenting bagi keberhasilan ekonomi. Hampir semua faktor produksi yang lainnya, yakni barang modal, bahan mentah serta teknologi, bisa dibeli atau dipinjam dari negara lain. Tetapi penerapan teknik-teknik produktivitas tinggi atas kondisi-kondisi lokal hampir selalu menuntut tersedianya manajemen, ketrampilan produksi, dan keahlian yang hanya bisa diperoleh melalui angkatan kerja terampil yang terdidik.

2. Sumber Daya Alam, faktor produksi kedua adalah tanah. Tanah yang dapat ditanami merupakan faktor yang paling berharga. Selain tanah, sumber daya alam yang penting antara lain minyak-minyak gas, hutan air dan bahan-bahan mineral lainnya.

3. Pembentukan Modal, untuk pembentukan modal, diperlukan pengorbanan berupa pengurangan konsumsi, yang mungkin berlangsung selama beberapa puluh tahun. Pembentukan modal dan investasi ini sebenarnya sangat dibutuhklan untuk kemajuan cepat di bidang ekonomi.

4. Perubahan Teknologi dan Inovasi, salah satu tugas kunci pembangunan ekonomi adalah memacu semangat kewiraswastaan. Perokonomian akan sulit untuk maju apabila tidak memiliki para wiraswastawan yang bersedia menanggung resiko usaha dengan mendirikan berbagai pabrik atau fasilitas produksi, menerapkan teknologi baru, mengadapi berbagai hambatan usaha, hingga mengimpor berbagai cara dan teknik usaha yang lebih maju (Samuelson, 1995).

Menurut Sukirno (1994) bahwa istilah pertumbuhan ekonomi menerangkan atau mengukur prestasi dari perkembangan dari suatu perekonomian, sedangkan dalam analisis makro ekonomi tingkat pertumbuhan ekonomi yang dicapai suatu negara diukur dari perkembangan pendapatan nasional riil yang dicapai suatu negara. Menurut Boediono (1992) pertumbuhan ekonomi adalah suatu proses dari kenaikan output perkapita dalam jangka waktu yang panjang. Pertumbuhan ekonomi disini meliputi 3 aspek yaitu: (1) Pertumbuhan ekonomi merupakan suatu proses (aspek ekonomis) suatu perekonomian berkembang, berubah dari waktu ke waktu; (2) pertumbuhan ekonomi berkaitan dengan adanya kenaikan output perkapita, dalam hal ini ada 2 aspek penting yaitu output total dan jumlah penduduk. Output perkapita adalah output total dibagi jumlah penduduk; dan (3) pertumbuhan ekonomi dikaitkan dengan perspektif waktu jangka panjang. Dikatakan tumbuh bila dalam jangka panjang waktu yang cukup lama (5 tahun) mengalami kenaikan output. (Adisetiawan dan Hasminidiarty, 2012)

Para ahli ekonomi menyatakan bahwa istilah pertumbuhan ekonomi berbeda dengan istilah pembangunan ekonomi. Pembangunan ekonomi diartikan sebagai suatu proses yang menyebabkan pendapatan perkapita penduduk suatu masyarakat meningkat dalam jangka panjang. Dari definisi ini mengandung tiga unsur yaitu: (1) pembangunan ekonomi sebagai suatu proses berarti perubahan yang terus-menerus yang didalamnya telah mengandung 
unsur-unsur kekuatan sendiri untuk investasi baru; (2) usaha meningkatkan pendapatan perkapita; dan (3) kenaikan pendapatan perkapita harus berlangsung dalam jangka panjang. (Adisetiawan, 2017)

Sanusi (2012) pembangunan ekonomi mengandung arti yang lebih luas serta mencakup perubahan pada susunan ekonomi masyarakat secara menyeluruh. Pembangunan ekonomi pada umumnya didefinisikan sebagai suatu proses yang menyebabkan kenaikan pendapatan riil perkapita penduduk suatu negara dalam jangka panjang yang disertai oleh perbaikan sistem kelembagaan. Dari definisi tersebut jelas bahwa pembangunan ekonomi mempunyai pengertian: (1) suatu proses yang berarti perubahan yang terjadi terus-menerus; (2) usaha untuk menaikkan pendapatan perkapita; (3) kenaikan pendapatan perkapita harus terus berlangsung dalam jangka panjang; dan (4) perbaikan sistem kelembagaan disegala bidang (misalnya ekonomi, politik, hukum, sosial dan budaya). Sistem ini bisa di tinjau dari dua aspek yaitu: aspek perbaikan di bidang organisasi (institusi) dan perbaikan di bidang regulasi (baik legal formal maupun informal).

\section{Model Pertumbuhan Ekonomi}

Pembangunan daerah dan pembangunan sektoral perlu selalu dilaksanakan dengan selaras, sehingga pembangunan sektoral yang berlangsung di daerah-daerah, benar-benar sesuai dengan potensi dan prioritas daerah. Dan keseluruhan pembangunan, daerah juga benar-benar merupakan satu kesatuan politik, ekonomi, sosial, budaya dan pertahanan keamanan di dalam mewujudkan tujuan nasional. Pembangunan daerah dilaksanakan agar ketimpangan pertumbuhan ekonomi antar daerah tidak semakin meluas. Tujuan pembangunan yang sedang dilaksankan mencakup sasaran seperti: Pertama, dalam usaha meratakan pembangunan di seluruh daerah, sekaligus untuk menghindari terjadinya jurang perbedaan tingkat pembangunan antar daerah yang semakin dalam. Kedua, pengarahan dalam kegiatan pembangunan daerah sesuai dengan kemampuan aspirasi dan potensi yang terdapat di daerah, baik bagi kepentingan perkembangan nasional maupun bagi kepentingan daerah sendiri. Ketiga, mengembangkan hubungan ekonomi antar daerah yang saling menguntungkan agar terjalin ikatan-ikatan (ekonomi) antar daerah yang kuat di dalam satu rangka kesatuan ekonomi nasional yang kokoh. Keempat, membina daerah-daerah minus, daerah perbatasan, dan tanah-tanah kritis, dengan program-program khusus (Sanusi, 1987).

Pembangunan daerah juga diarahkan untuk mencapai tiga tujuan penting yaitu mencapai pertumbuhan (growth), pemerataan (equity), dan keberlanjutan (sustainability). Tujuan pembangunan yang pertama, untuk pertumbuhan ditentukan sampai dimana kelangkaan sumber daya yang terdiri atas sumber daya manusia (human capital), peralatan (man made resources) dan sumber daya alam (natural resources) dapat dialokasikan secara maksimal dan dimanfaatkan untuk meningkatkan kegiatan produktif. Dalam hal ini terdapat upaya memadukan kemampuan sumber daya manusia dan pemanfaatan sumber daya alam dengan ketersediaan sumber daya alam dan sumber daya buatan dengan teknologi dalam rangka memperbesar produktifitas. Semakin tinggi tingkat kemampuan sumber daya manusia, besar kemungkinan untuk memanfaatkan sumber daya alam yang tersedia guna mencapai pertumbuhan yang tinggi. Sedangkan tujuan pembangunan yang kedua, yaitu pemerataan yang mempunyai implikasi dalam pencapaian tujuan yang ketiga supaya sumber daya dapat berkelanjutan maka tidak boleh terfokus hanya pada satu daerah saja sehingga manfaat yang diperoleh dari pertumbuhan dapat dinikmati semua pihak. Sedangkan tujuan berkelanjutan, pembangunan daerah harus memenuhi persyaratan bahwa penggunaan sumber daya, baik yang ditransaksikan melalui sistem pasar maupun diluar sistem pasar harus tidak melampaui kapasitas kemampuan produksi. (Adisetiawan dan Ahmadi, 2016)

\section{Produk Domestik Regional Bruto (PDRB)}

PDRB merupakan penjumlahan dari semua harga dan jasa akhir atau semua nilai tambah yang dihasilkan oleh daerah dalam periode waktu tertentu (1 tahun). Untuk menghitung nilai seluruh produksi yang dihasilkan suatu perekonomian dalam suatu tahun tertentu dapat digunakan 3 cara penghitungan. Ketiga cara tersebut adalah: 
1. Cara Pengeluaran, dengan cara ini pendapatan nasional dihitung dengan menjumlah pengeluaran ke atas barang-barang dan jasa yang diproduksikan dalam negara tersebut. Menurut cara ini pendapatan nasional adalah jumlah nilai pengeluaran rumah tangga konsumsi, rumah tangga produksi dan pengeluaran pemerintah serta pendapatan ekspor dikurangi dengan pengeluaran untuk barang-barang impor.

2. Cara Produksi atau cara produk netto, dengan cara ini pendapatan nasional dihitung dengan menjumlahkan nilai produksi barang atau jasa yang diwujudkan oleh berbagai sektor (lapangan usaha) dalam perekonomian. Dalam menghitung pendapatan nasional dengan cara produksi yang dijumlahkan hanyalah nilai produksi tambahan atau value added yang diciptakan.

3. Cara Pendapatan, dalam penghitungan ini pendapatan nasional diperoleh dengan cara menjumlahkan pendapatan yang diterima oleh faktor-faktor produksi yang digunakan untuk mewujudkan pendapatan nasional. (Sukirno, 1994).

Adapun manfaat penghitungan nilai PDRB adalah: (1) mengetahui dan menelaah struktur atau susunan perekonomian. Dari perhitungan PDRB dapat diketahui apakah suatu daerah termasuk daerah industri, pertanian atau jasa dan berapakah besar sumbangan masing-masing sektornya; dan (2) membandingkan perekonomian dari waktu ke waktu. Oleh karena nilai PDRB dicatat tiap tahun, maka akan di dapat catatan angka dari tahun ke tahun. Dengan demikian diharapkan dapat diperoleh keterangan kenaikan atau penurunan apaka ada perubahan atau pengurangan kemakmuran material atau tidak. (Adisetiawan dan Ahmadi, 2016)

\section{Pendapatan Asli Daerah (PAD)}

Pendapatan asli daerah adalah penerimaan daerah dari berbagai usaha pemerintah daerah untuk mengumpulkan dana guna keperluan daerah yang bersangkutan dalam membiayai kegiatan rutin maupun pembangunannya, yang terdiri atas pajak daerah, retribusi daerah, bagian laba usaha milik daerah, dan lain-lain penerimaan asli daerah yang sah. Pendapatan asli daerah diartikan sebagai pendapatan daerah yang tergantung keadaan perekonomian pada umumnya dan potensi dari sumber-sumber pendapatan asli daerah itu sendiri. Sutrisno (1984) pendapatan asli daerah adalah suatu pendapatan yang menunjukkan kemampuan suatu daerah untuk menghimpun sumber-sumber dana untuk membiayai kegiatan daerah. Jadi pengertian pendapatan asli daerah dapat dikatakan sebagai pendapatan rutin dari usaha-usaha pemerintah daerah dalam memanfaatkan potensi-potensi sumbersumber keuangan untuk membiayai tugas-tugas dan tanggungjawabnya. Menurut pasal 6 Undang-undang No. 32 Tahun 2012 pendapatan asli daerah berasal dari : hasil pajak daerah, hasil retribusi daerah, hasil perusahaan milik daerah dan hasil pengelolaan kekayaan daerah yang dipisahkan; dan penerimaan dari dinas dan lain-lain pendapatan daerah yang sah.

\section{Tingkat Investasi}

Investasi dapat diartikan sebagai pengeluaran atau perbelanjaan penanam-penanam modal atau perusahaan untuk membeli barang-barang modal dan perlengkapan-perlengkapan produksi untuk menambah kemampuan memproduksi barang-barang dan jasa-jasa yang tersedia dalam perekonomian (Sukirno, 1994). Investasi tidak hanya untuk memaksimalkan output, tetapi untuk menentukan distribusi tenaga kerja dan distribusi pendapatan, pertumbuhan dan kualitas penduduk serta teknologi.

Investasi swasta di Indonesia dijamin keberadaannya sejak dikeluarkannya Undangundang No.1 Tahun 1967 tentang penanaman modal asing dan Undang-undang No. 6 Tahun 1968 tentang penanaman modal dalam negeri, yang kemudian dilengkapi dan disempurnakan dengan Undang-undang No.11 Tahun 1970 tentang penanaman modal asing dan Undangundang No.12 Tahun 1970 tentang penanaman modal dalam negeri. Berdasarkan dari sumber kepemilikan modal, maka investasi swasta dapat di bagi menjadi penanaman modal asing dan penanaman modal dalam negeri. Investasi atau pengeluaran-pengeluaran untuk membeli barang modal dan peralatan-peralatan produksi dengan tujuan mengganti dan untuk menambah barang-barang modal dalam perekonomian yang akan digunakan untuk memproduksikan barang dan jasa di masa depan. Investasi atau pengeluaran untuk membeli 
barang-barang modal dan peralatan produksi dibedakan menjadi investasi perusahaan swasta, perubahan inventaris perusahaan dan investasi yang dilakukan oleh pemerintah. Investasi perusahaan merupakan komponen yang terbesar dari investasi dalam suatu negara. Pengeluaran investasi tersebut terutama meliputi mendirikan bangunan industri, membeli mesin-mesin dan peralatan produksi lain dan pengeluaran untuk menyediakan bahan mentah. Investasi yang dilakukan dimasa kini sangat erat hubungannya dengan prospek memperoleh keuntungan di masa depan.

Peranan kunci kepada investasi terhadap peranannya dalam proses pertumbuhan ekonomi khususnya mengenai watak ganda yang dimiliki investasi. Pertama, investasi memiliki peran ganda dimana dapat menciptakan pendapatan, dan kedua, investasi memperbesar kapasitas produksi perekonomian dengan cara meningkatkan stok modal (Jhingan, 1999).

\section{Tenaga Kerja dan Angkatan Kerja}

Tenaga kerja adalah penduduk pada usia kerja yaitu antara 15-64 tahun. Penduduk dalam usia kerja ini dapat digolongkan menjadi dua yaitu angkatan kerja dan bukan angkatan kerja. (Suparmoko, 2002). Secara ringkas, tenaga kerja terdiri atas angkatan kerja dan bukan angkatan kerja. Yang dimaksud dengan angkatan kerja adalah bagian dari tenaga kerja yang terlibat atau masih berusaha uantuk terlibat dalam kegiatan produktif yang menghasilkan barang dan jasa. Menurut Suparmoko (2002) angkatan kerja adalah penduduk yang belum bekerja namun siap untuk bekerja atau sedang mencari pekerjaan pada tingkat upah yang berlaku. Angkatan kerja terdiri atas golongan yang bekerja, dan golongan yang menganggur dan mencari pekerjaan (Simanjuntak, 1985). Sedangkan yang dimaksud dengan bukan angkatan kerja adalah mereka yang masih sekolah, golongan yang mengurus rumah tangga, dan golongan lain-lain atau penerima pendapatan (Simanjuntak, 1985). Jika yang digunakan sebagai satuan hitung tenaga kerja adalah orang, maka disini dianggap bahwa semua orang mempunyai kemampuan dan produktifitas kerja yang sama dan lama waktu kerja yang dianggap sama. Penggunaan tenaga kerja hanya bisa diwujudkan kalau tersedia dua unsur pokok, yang pertama adalah adanya kesempatan kerja yang cukup banyak, yang produktif dan memberikan imbalan yang baik. Dan yang kedua, adalah tenaga kerja yang mempunyai kemampuan dan semangat kerja yang cukup tinggi. Kesempatan kerja dapat tercipta jika terjadi permintaan akan tenaga kerja di pasar kerja. Besarnya tenaga kerja dalam jangka pendek tergantung dari besarnya efektifitas permintaan untuk tenaga kerja yang dipengaruhi oleh kemampuankemampuan substitusi antara tenaga kerja dan faktor produksi yang lain, elastisitas permintaan akan hasil produksi, dan elastisitas penyediaan faktor-faktor pelengkap lainnya. Dalam statistik ketenagakerjaan di Indonesia kesempatan kerja merupakan terjemahan bagi employment yang berarti sebagai jumlah orang yang bekerja tanpa memperhitungkan berapa banyak pekerjaan yang dimiliki tiap orang, pendapatan dan jam kerja mereka.

\section{METODE}

Jenis penelitian dari segi pendekatan dibagi menjadi dua macam yaitu, pendekatan kuantitatif dan pendekatan kualitatif. Sedangkan dalam penelitian ini menggunakan pendekatan kuantitatif. Pendekatan kuantitatif pada dasarnya menekankan analisisnya pada data-data numerikal (angka) yang diolah dengan metode statistika. Pada dasarnya, pendekatan kuantitatif dilakukan pada penelitian inferensial (dalam rangka pengujian hipotesis) dan menyandarkan kesimpulan hasilnya pada suatu probabilitas kesalahan penolakan hipotesis nihil. Dengan metode kuantitatif akan diperoleh signifikansi perbedaan kelompok atau signifikansi hubungan antar variabel yang diteliti (Azwar, 2001). Variabel penelitian adalah suatu gejala yang bervariasi. Variabel juga dapat diartikan sebagai obyek penelitian yang menjadi titik pusat perhatian dari suatu penelitian. Variabel dalam penelitian ini antara lain : Variabel Bebas (Independent Variables)

Variabel bebas adalah suatu variabel yang variasinya mempengaruhi variabel lain. Dapat pula dikatakan bahwa variabel bebas adalah variabel yang pengaruhnya terhadap variabel lain ingin diketahui (Azwar, 2001). Dalam penelitian ini yang menjadi variabel bebas antara lain : 
a. Tingkat Investasi, tingkat investasi merupakan jumlah uang yang ditanamkan untuk pembangunan industri atau proyek-proyek Penanaman Modal Asing maupun Penanaman Modal Dalam Negeri. Investasi adalah pengeluaran atau perbelanjaan penanam-penanam modal atau perusahaan untuk membeli barang-barang modal untuk menambah kemampuan memproduksi barang dan jasa yang tersedia dalam perekonomian (Sukirno, 1994).

b. Pendapatan Asli Daerah, pendapatan Asli Daerah yaitu pendapatan yang berasal dari dalam daerah yang bersangkutan yang merupakan hasil pajak daerah, hasil retribusi daerah, hasil laba perusahaan milik daerah dan juga pendapatan lainnya daerah yang sah. PAD adalah suatu pendapatan yang menunjukkan kemampuan suatu daerah untuk menghimpun sumber-sumber dana untuk membiayai kegiatan daerah (Sutrisno, 1984). Menurut pasal 6 Undang-undang No. 32 tahun 2012, PAD berasal dari pajak daerah, retribusi daerah, bagian laba perusahaan daerah, dan penerimaan dinas dan pendapatan lain-lain yang disahkan.

c. Tenaga Kerja, tenaga kerja adalah penduduk pada usia kerja yaitu antara 15 sampai dengan 64 tahun (Suparmoko, 2002). Tenaga kerja adalah penduduk dalam usia kerja atau jumlah seluruh penduduk dalam suatu negara dalam memproduksi barang dan jasa jika ada permintaan terhadap tenaga mereka, dan jika mereka mau berpartisipasi dalam aktivitas tersebut.

Variabel terikat/tergantung (Dependent Variables)

Variabel tergantung adalah variabel penelitian yang diukur untuk mengetahui besarnya efek atau pengaruh variabel yang lain. Besarnya efek tersebut diamati dari ada tidaknya, timbul-hilangnya, membesar-mengecilnya, atau berubahnya variasi yang tampak sebagai akibat perubahan pada variabel lain termasud (Azwar, 2001). Variabel terikat atau tergantung dalam penelitian ini adalah PDRB. PDRB yaitu jumlah nilai produksi netto dari suatu barang dan jasa yang dihasilkan daerah dalam jangka waktu tertentu (satu tahun). Data yang dipergunakan dalam penelitian ini adalah data sekunder yang berupa data time series periode tahun 20122016. Data sekunder adalah data yang diperoleh lewat pihak lain, tidak langsung diperoleh dari peneliti dari subyek penelitiannya. Data sekunder biasanya berwujud data dokumentasi atau data laporan yang telah tersedia (Azwar, 2001). Data yang digunakan meliputi: data PDRB, data tingkat investasi, data pendapatan asli daerah, dan data tenaga kerja. Data ini diperoleh dari Badan Pusat Statistik Provinsi Jambi.

\section{HASIL}

Tabel 1. Rangkuman hasil analisis

\begin{tabular}{|c|c|c|c|c|c|}
\hline \multirow{2}{*}{ Variabel } & \multirow{2}{*}{ koefisien } & \multirow{2}{*}{ Sig } & \multirow{2}{*}{$\begin{array}{l}\text { Determinasi } \\
\text { partial }\end{array}$} & \multicolumn{2}{|c|}{ Collinearity Statistic } \\
\hline & & & & Tolerance & VIF \\
\hline Tingkat investasi & 0,001 & 0,531 & 0,672 & 0,373 & 2,678 \\
\hline PAD & 0,634 & 0,987 & 0,020 & 0,364 & 2,745 \\
\hline Tenaga Kerja & 0,123 & 0,461 & 0,479 & 0,954 & 1,049 \\
\hline
\end{tabular}

Sumber: data olahan yaitu:

Setelah menggunakan perhitungan komputer program SPSS diperoleh persamaan regresi $\mathrm{Y}=65,082+0,001 \mathrm{X} 1+0,634 \mathrm{X} 2+0,123 \mathrm{X} 3$

Persamaan regresi linear di atas dipengaruhi oleh nilai koefisien $\beta_{1}, \beta_{2}$, dan $\beta_{3}$. Nilai koefisien positif maka dapat diartikan bahwa setiap kenaikan nilai Tingkat investasi, PAD, dan Tenaga kerja sebesar satu satuan maka akan diikuti kenaikan nilai upah minimum satu satuan. Kesimpulan dari persamaan di atas adalah: 
a. Konstanta sebesar 65,082 artinya bahwa jika tingkat investasi, PAD dan tenaga kerja dalam artian nilai variabel independen nol maka nilai Produk Domestik Regional Bruto secara konstan nilai 65.082

b. Koefisien regresi X1 sebesar 0,001 artinya bahwa tingkat investasi naik satu satuan maka PDRB akan mengalami kenaikan sebesar 0,1\% atau 0,001dengan asumsi variabel lain tetap.

c. Koefisien regresi X2 sebesar 0,634 artinya jika PAD naik satu satuan maka PDRB akan mengalami kenaikan sebesar $63,4 \%$ atau 0,634 .

Koefisien regresi X3 sebesar 0,123 artinya jika tenaga kerja naik satu satuan maka PDRB akan mengalami kenaikan sebesar $123 \%$ atau 0,123. Hasil regresi yang telah diuraikan pada hasil penelitian ada beberapa hal yang dapat dibahas untuk diketahui lebih lanjut :

a. Pendapatan Asli Daerah (PAD) sebagai indikator kemandirian daerah mengalami kenaikan dari tahun ke tahun. Kontribusi PAD terhadap penerimaan total Provinsi Jambi mencapai 75 persen pada tahun 2016. Kondisi tersebut dapat diindikasikan sebagai kesiapan daerah dalam membiayai sendiri pembangunan yang juga merupakan tujuan pelaksanaan otonomi daerah. Peningkatan PAD diperoleh dari peningkatan jumlah obyek pajak yang diserahkan pemerintah daerah. PAD sebagai modal utama pembangunan daerah dapat digunakan pada sektor publik yang mendukung berkembangnya produksi dan pasar daerah. Dalam penelitian ini PAD berpengaruh cukup signifikan terhadap PDRB Provinsi Jambi, dengan sumbangan parsial sebesar 75,7\% terhadap PDRB Provinsi Jambi. Dengan pembelanjaan yang tepat sasaran dan sesuai potensi unggul yang dimiliki oleh daerah maka diharapkan mampu mempercepat pertumbuhan ekonomi daerah untuk kesejahteraan masyarakat.

b. Investasi, investasi swasta mutlak dan perlu dikembangkan untuk mendukung pertumbuhan ekonomi khususnya di Provinsi Jambi. Berdasarkan uji t dengan tingkat signifikansi 5\%, sedangkan nilai signifikansi tingkat investasi sebesar 0,531 dan disimpulkan bahwa tingkat investasi ini tidak berpengaruh signifikan terhadap pertumbuhan ekonomi Provinsi Jambi. Sumbangan parsial dari variabel tingkat investasi terhadap PDRB Provinsi Jambi ini sebesar 53\%. Investasi atau pembentukan modal ini merupakan hal yang sangat penting untuk dapat menggerakkan perkonomian suatu daerah, sedangkan nilai investasi di Provinsi Jambi yang fluktuatif kurang menguntungkan untuk dapat meningkatkan pertumbuhan ekonomi daerah. Masih rendahnya nilai investasi di Provinsi Jambi ini terjadi antara lain karena masih tingginya pungutan yang terjadi untuk melakukan investasi, selain itu faktor perijinan yang memakan waktu yang lama juga menyebabkan makin kurang berminatnya investor untuk menginvestasikan modalnya walaupun mekanisme pelayanan satu atap atau one stop service sudah diterapkan dihampir seluruh Provinsi Jambi. Selain itu, iklim investasi ini diperburuk oleh rendahnya pelayanan publik, kurangnya kepastian hukum, dan berbagai peraturan daerah yang tidak pro bisnis. Pelayanan publik yang dikeluhkan terutama terkait dengan ketidakpastian biaya dan lamanya waktu berurusan dengan perijinan dan birokrasi. Selain itu, peningkatan penerimaan daerah dengan optimalisasi pajak sebagai konsekuensi ototnomi daerah juga merupakan salah satu kendala bagi investor yang masuk ke daerah. Banyaknya peraturan daerah yang dibuat untuk meningkakan penerimaan daerah ini berakibat semakin tercekiknya dunia bisnis.

c. Tenaga Kerja, sumber daya manusia memiliki peran penting dalam pembangunan daerah. Berdasarkan uji t dengan tingkat signifikansi 5 persen diketahui bahwa tenaga kerja tidak berpengaruh signifikan terhadap pertumbuhan ekonomi. Pertumbuhan penduduk (bertambahnya tenaga kerja) dalam jangka panjang akan menurunkan kembali tingkat pembangunan ke tahap yang lebih rendah. Ini terjadi karena hukum kenaikan hasil yang semakin berkurang, karena dalam jangka panjang perekonomian akan mencapai keadaan stationary state Dengan rendahnya tingkat investasi maka lapangan pekerjaan yang tersedia juga semakin sedikit sehingga produkivitas yang dihasilkan juga semakin menurun. Untuk dapat meningkatkan poduktivitas maka yang diperlukan adalah peningkatan akumulasi modal. Jumlah penduduk yang banyak tetapi efisiensi dan produktifitas sangat tinggi ini akan dapat meningkatkan laju pertumbuhan ekonomi. 


\section{SIMPULAN}

Pembahasan diatas maka didapat kesimpulan sebagai berikut :

1. Tingkat investasi dalam penelitian ini secara parsial tidak berpengaruh signifikan terhadap pertumbuhan ekonomi Provinsi Jambi. Nilai investasi di Provinsi Jambi tergolong masih rendah, antara lain dikarenakan proses perijinan yang sangat rumit sehingga menyebabkan ekonomi biaya tinggi.

2. Pendapatan Asli Daerah merupakan indikator kemandirian daerah, sehingga nilai dari PAD ini diharapkan dapat tumbuh dari tahun ke tahun. Dalam penelitian ini PAD mempunyai pengaruh yang signifikan terhadap pertumbuhan ekonomi di Provinsi Jambi. Dengan determinasi parsial yang mencapai 75,7 persen terhadap PDRB, di harapkan dengan pembelanjaan yang tepat sasaran dan di sektor yang potensial maka pertumbuhan ekonomi dapat meningkat.

3. Tenaga kerja merupakan salah satu faktor yang dapat meningkatkan pertumbuhan ekonomi. Tetapi dalam jangka panjang pertumbuhan penduduk (bertambahnya angkatan kerja) dapat menurunkan kembali pembangunan ke tahap yang rendah. Dalam penelitian ini tenaga kerja tidak berpengaruh signifikan terhadap pertumbuhan ekonomi Provinsi Jambi.

\section{DAFTAR PUSTAKA}

Adisetiawan., R dan Hasminidiarty, 2012, Analisis Pengaruh Variabel-variabel Makroekonomi dan Mikroekonomi Terhadap Investasi Saham, Jurnal Ekonomi, 16(2), 159-174

Adisetiawan, R., 2014, Keseimbangan Jangka Panjang antara Variabel Makro Ekonomi dengan Indeks Harga Saham, Trikonomika Journal, 10(2), 72-84

Adisetiawan., R. dan Ahmadi, 2016, The Impact of Earnings Management Against Market Reaction: Empirical Evidance From Indonesia, International Research Journal of Finance and Economics, 146, 112-128

Adisetiawan, R., 2017, Globalisasi Pasar Modal Dunia dan Pengaruhnya Terhadap Pasar Modal Indonesia, Ekonomis: Journal of Economics and Business, 1(1), 10-17

Adisetiawan, R., 2018, Kausalitas Ekonomi Makro dan Global Terhadap Pasar Modal Indonesia, Ekonomis: Journal of Economics and Business, 2(1), 66-80

Azwar, Saifudin. 2001. Metode Penelitian. Yogyakarta: Pustaka Pelajar Offset

Boediono. 1992. Teori Pertumbuhan Ekonomi, Seri Sinopsis Pengantar Ilmu Ekonomi. No.4.Yogyakarta: BPFE

Hasibuan, Malayu S.P. 1987. Ekonomi Pembangunan dan Perekonomian Indonesia. Bandung : Armico.

Jhingan, M. L. 1999. Ekonomi Pembangunan dan Perencanaan. Jakarta: Raja Grafindo

Samuelson, Paul A. Dan Nordhaus William D. 1995. Ekonomi (Edisi Terjemahan). Edisi 12 jilid 2. Jakarta : Erlangga

Sanusi, Bachrawi. 2012. Pembangunan Daerah dilihat dari Potensi Energi. Jakarta: LPFE UI

Simanjuntak, Payaman. 1985. Pengantar Imu Ekonomi Sumber Daya Manusia. Jakarta: LPFE UI

Sukirno, Sadono. 1994. Pengantar Teori Makro Ekonomi. Edisi 2. Jakarta: Raja Grafindo Persada Suparmoko, M. 2002. Ekonomika Pembangunan. Jakarta : BPFE

Sutrisno. 1984. Dasar-dasar Ilmu Keuangan Negara. Yogyakarta: BPFE UI

Zaris, Roeslan. 1987. Prespektif Daerah dalam Pembangunan Nasional. Jakarta LPFE UI 